N. Mazaraki, Dr. Sc. (Jurid.), Assoc. Prof., orcid.org/0000-0002-1729-7846,

A. Gerasymenko, Dr. Sc. (Econ.), Prof., orcid.org/0000-0003-0313-6942,

V. Kovtun,

orcid.org/0000-0003-2956-8647
Kyiv National university of trade and economics, Kyiv, Ukraine, e-mail: n.mazaraki@knute.edu.ua; a.gerasymenko@ $\underline{\text { knute.edu.ua }}$

\title{
INFORMATION ASYMMETRY AS A DETERMINANT OF COMPETITION
}

Purpose. Defining the impact of information asymmetry on basic competitive strategies of market participants, as well as revealing the vector of competition change while information asymmetry increases.

Methodology. The methodological basis of the study is a comparative analysis of fuel retail markets in Ukraine and passenger air transportation. These markets are considered as examples of markets characterized by different levels of information asymmetry with the same structural parameters, which makes it possible to establish the effect of information asymmetry on competition.

Findings. Comparisons of the retail fuel market and the passenger air transport market indicate that information asymmetry influences market participants' choice of a basic competition strategy. Thus, information asymmetry weakens price competition and increases the non-price competition, weakening the intensity of competition between participants in market relations and creating the preconditions for increasing their dynamic competitiveness. This influence of information asymmetry on competition and social well-being is essentially positive. However, a long-lasting negative effect is also observed - information asymmetry deforms consumer perception of the market balance parameters so much that lower competitive intensity and a wide range of balance are not perceived negatively, and the seller receives a guarantee of positive economic profit. This negative effect catches on due to the spread of information asymmetry (as a profitable and legal practice) throughout the markets, ensuring its strengthening. The latter requires the development of new approaches to assessing the effectiveness of market competition while the "structure - conduct - performance" paradigm appears to be insensitive to information asymmetry effects on competition.

Originality. In the course of the study we concluded that the classification of goods according to the degree of their favourability to information asymmetry into search, experience and credence goods is purely theoretical. In their pure form in practice, they are virtually not encountered; this is precisely why a special propensity curve for information asymmetry has been developed, on which goods approaching to the status of credence ones have the highest propensity for manifestations of information asymmetry.

Practical value. The methodology of market research proposed in the work may be the basis for a better choice of competitive strategy by economic entities or a more effective study of the situation in the markets by consulting agencies and public authorities.

Keywords: information economy, information asymmetry, competition, price competition, differentiation of goods, retail market for fuel, passenger air transport market

Introduction. Evolution of the information economy in recent decades has been conventionally illustrated with examples of markets for innovative products and trends for their globalization. In fact, the extent of its penetration is much greater. It affects all the markets of goods and services without any exception and is manifested in the behaviour of the most firms. Let us talk about the phenomenon of information asymmetry. It is not a new one. In some ways, it has been manifested in economic activity for years, being mainly the negative externality (some kind of market failure). Nowadays, information asymmetry is transforming into the applied competition tool. Businesses purposely create or enhance the information asymmetry as a source of their own competitive advantage or as a competition tool.

Awareness of the above-described changes by individual market participants, as well as their consideration in the development of competitive strategies can be observed in the activities of leading market players, especially, in those sectors, which have been traditionally characterized by the high degree of information asymmetry and high concentration of credence goods (finance, education, medicine, and others). They have already learned how to use this economic phenomenon for their own benefit and disseminate these practices even onto the markets for standardized search goods. It requires the unification of the tools of information asymmetry research that in the meantime remains specialized to the needs of individual markets and industries, providing a fragmentary reflection of the problem.

Literature review. Economics has developed many different techniques of information asymmetry research. Many of them are developed for investigation of information asymme-

(C) Mazaraki N., Gerasymenko A., Kovtun V., 2020 try influence on market performance at large and on the economic choice of market actors particularly. Among them are the papers by R. Decourt, H. Almeida and P. Protin [1], Martins and E. Paulo [2], T. Jonson and E. So [3] and others.

The problem with these techniques is their narrow specialization and extremely high input requirements, which can be met only for a limited range of markets. Being effective, for example, in the stock market they prove to be completely unsuitable for understanding the actual impact of information asymmetry on the behaviour of consumers, suppliers, competitors in other markets, and competition in general.

Purpose. Responding to the above-mentioned problem, the article is aimed at investigation of the impact of information asymmetry on basic competitive strategies of market participants, as well as the reveal of the vector of competition change while information asymmetry increases.

Methods. The article provides comparative analysis of retail fuel markets in Ukraine and passenger air transportation as examples of markets, which are characterized by different levels of information asymmetry with the same structural parameters, to reveal the effect of information asymmetry on competition.

Results. The research needs to fix on two markets with different levels of information asymmetry and the most similar other determinants of competition. Following the "structure conduct - performance" paradigm (SCP paradigm), which defines the dominant role of structural prerequisites for competition in the market, we have identified initial levels of market concentration as a crucial selection factor. In response to the critique of this paradigm by representatives of the Chicago School of Economics, the corresponding criterion was supplemented by the requirement of an identical role distribution between market actors in the course of competitive interaction [4]. 
Best of all this triad of requirements was met for a couple of such markets - retail fuel market and market of air-passenger operations. Both markets are characterized by similar levels of market concentration (Table 1) and role-playing models: each market has a dominant company with a share of about $30 \%$, which sets the rules of the market game, a small number of notable competitors, which can exert some influence on these rules, and dispersed competitive fringe, which is a subject to these rules [4].

In contrast to the structural parameters, transparency and accessibility for competitors of information about each other in these markets differ significantly. There are differences in access of compared markets' actors to such sensitive information as prices, quality of the goods or services, and the services themselves are characterized by different degree of differentiation - the parameter that is directly proportional to the level of information asymmetry in the market.

Let us start by analysing the price parameter. Pursuant to Article 8 of the Petroleum Retail Rules, information on retail prices, brands and types of petroleum products sold at a gas station must be indicated on a special information board installed at each gas station entrance [7].

Accordingly, the prices at which fuel is traded at each time point at each gas station are obvious to anyone travelling through the station, including competitors. In addition, there are large number of consulting companies such as UPECO, SC "Psyche", Pro-Consulting, and others, which are engaged in market research and can provide qualified information services, as well as publish the results of their own monitoring of fuel prices in Ukraine, which the State Statistics Service of Ukraine also does. Relevant data are available on daily basis by regions of Ukraine, companies and brands.

The situation with airfares is different. According to the information specified in the Rules of Carriage of Passengers and Luggage of one of the largest air carriers in Ukraine, the airfare is the amount established by a carrier for the carriage of passengers, a unit of luggage weight (cargo) on the respective route according to the relevant class of service. Rates may be both published and confidential.

The published airline rates are controlled by the International Air Transport Association. They are mainly used to calculate complex routes involving multiple carriers. Tickets for published fares can be purchased anywhere in the world, but their price is usually very high compared to confidential tariff offers on the market. Confidential rates are formed by the airlines on their own taking into account the demand, competition and strategy of the company in a particular direction. These rates are a trade secret for competitors, operated by an airline itself and its agents.

The situation is complicated by the differentiated nature of air-passenger operations. Despite the availability of a number of travel fare aggregators, such as skyscanner, tickets.ua, kyiavia, and others, which allow a customer to compare ticket prices for different airlines, such a comparison gives almost nothing to competitors in terms of understanding each other's pricing strategies. The price of a ticket for the same flight of the same airline may vary several times, depending on the class of

Table 1

Comparison of market concentration in retail trade in fuel and air-passenger operations, 2018 [5, 6]

\begin{tabular}{|l|c|c|}
\hline \multicolumn{1}{|c|}{ Indicator } & Retail fuel market & $\begin{array}{c}\text { Market of } \\
\text { air-passenger } \\
\text { operations }\end{array}$ \\
\hline Market concentration & CR1 $=33.25 ;$ & CR1 $=30.61 ;$ \\
coefficients & CR3 $=62.55 ;$ & CR3 $=58.11 ;$ \\
CR5 $=73.25$ & 0.11 .21 \\
\hline Herfinal-Hirschman Index & 0.1652 & 0.1513 \\
\hline
\end{tabular}

service and the class of booking (there are 26 booking classes, which use depends on both the offers of the airline and the characteristics of an individual passenger), on the flight distance, the number of transfers, time of flight and time of booking a ticket, the scope of additional services (priority boarding, transportation of luggage, meals on board, and so on), aircraft type, and others. It may change several times a day.

Accordingly, competitors can only make a very broad picture of each other's pricing strategies, such as whether the company is a low-cost carrier or is positioning itself as a premium carrier. The same awareness is significantly different from the price information that competitors in the retail fuel market have, allowing us to use these two markets as a benchmark.

As noted above, the much-described differences in access to pricing information are the result of differences in the services provided, primarily in their typology and degree of differentiation. In the Industrial Economics, it is used to distinguish three types of goods, depending on their propensity for information asymmetry: search goods, experience goods and credence goods. Obviously, such a distribution is mainly theoretical and does not occur in practice in its pure form; however, by analysing the markets chosen, we can at least place their goods along some information asymmetry propensity line, at which mark 0 reflects the minimum and mark $1-$ the maximum propensity to information asymmetry (Figure).

Retail fuel services in the Figure are located in the interval between the search goods and the experience goods, being characterized by the presence of features of each type. On the one hand, fuels including motor gasoline of the respective brands, diesel, etc., sold at gas stations with the prices, which by $80 \%$ depends on cost of input fuel and the taxes, are standardized search goods [7]. On the other hand, the fact that all retailers are adhering to established standards is controversial. Another factor of product differentiation is terms of sale: starting from the assortment of ancillary services - car washing, catering, purchasing food and non-food items, and others, and ending with staff friendliness that can influence consumer choice or forcing him/her to return to the relevant retailer or to stop purchase fuel at the gas station. The latter brings forward retail fuel services to experience goods within the information asymmetry propensity line.

With regard to air-passenger operations, the situation is much more complicated. In the airline industry, as well as in the fuel industry, there are mandatory standards. All indicators concerning safety, airworthiness, flight staff in the field of air transportation are standardized and strictly regulated by public authorities, in particular the State Aviation Service of Ukraine, and are binding on all carriers. That is, beyond the immediacy of the distribution of aviation service by class, it could be argued that these standards determine the basic air passenger service, which is characterized by zero level of differentiation. The list of differentiation features here is very wide, including class distribution, duration of flights, the number of transfers and convenience of connections, availability of additional services from luggage transportation to the ability to return or exchange a ticket, and so on. The fact of providing a number of these services can be learned before the flight, while their quality - only on the back of the consumption. The term "quality of air-passenger operations" includes convenience of passenger seats, friendliness and qualification of staff, taste and variety of food on board, and others. The overall impression of a flight can be ruined by circumstances that often do not even depend on the carrier - for example, flight delays due to bad weather or the presence of uncon-

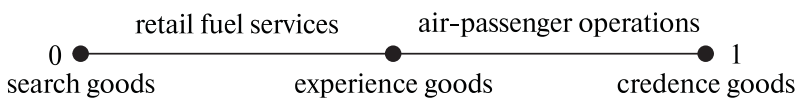

Fig. Positioning of retail fuel services and air-passenger operations along the information asymmetry propensity line 
trolled passengers on board. In the case of force-majeure the quality of the air-passenger operations will be determined by the response of the airline employees to such circumstances, their ability to solve the problem with minimal loss to the consumer. Since force majeure occasionally occurs, even the long-term deal with the same airline does not give the consumer sufficient information about the quality of the service received. The consumer never knows the real reason of his/her successful trip - good weather conditions or the pilots' high skills, etc. This factor moves the air-passenger operations towards credence goods as a last resort of market favouring the spread of information asymmetry.

Modern technologies, the availability of online resources such as tripadvisor, avianews.com and others help to assess the quality of air-passenger operations of a particular carrier, but the comments collected there are subjective. In order to obtain more accurate analytical conclusion, it is necessary to examine thousands of comments and reviews, which significantly increases transaction costs and effectively negates the ability to pre-set the quality of air-passenger operations. This is a reason of a high level of information asymmetry in the market.

Therefore, comparing these markets with respect to information transparency, we can conclude that the retail fuel market is much more transparent than the market for air-passenger operations. Information about prices, goods, terms of sale in the retail fuel market spreads much faster, easier and with a lesser degree of its deformation in the process of distribution, both because of the specific nature of retail sale of homogeneous product, and in view of the institutional environment of the relevant market. The market of air-passenger operations, which is characterized by the presence of differentiated goods with certain features of the credence goods and by institutional regulations that are much less rigid in the information sense, (for example, they allow the existence of confidential tariffs in the market), is a favourable environment for the dissemination of information asymmetry among participants.

Thus, the main criteria for selecting markets to investigate the impact of information asymmetry on competitive relations are fulfilled. The retail fuel market and market of air-passenger operations are similar in terms of structural prerequisites to competition and different in terms of information asymmetry. Comparing the competition strategies of these two markets' actors, let us evaluate the impact of information asymmetry on competition relations.

Following the positions by J. Stiglitz and J. Stigler we determine information asymmetry via its ability to institutionalize multiple market equilibria. The term "market equilibrium" in the mainstream economics is mainly understood as a certain correspondence of price and output, which means the existence of some price corridor in the market, affected by information asymmetry. Starting with this, as well as with the fact that price competition was chronologically the first manifestation of competition, let us begin our comparative analysis with the assessment of the intensity of price competition in the comparable markets. For this purpose, let us analyse the price dispersion in the markets, as J.Stigler did, and compare the obtained values of the coefficients of price variation.

The input of the study was the data of SC "Psyche" on the dynamics of retail prices for different types of fuel (gasoline A-95, A-92, diesel and liquefied natural gas) across gas station brands in July-August 2018 and the data of the travel fare aggregators, such as skyscanner, tickets.ua, kyiavia, tripadvisor, avianews. com, on prices of air-passenger operations (flights) by different airlines (overall and per $1 \mathrm{~km}$ flight distance) for 50 destinations departing from Kyiv during the same period, broken down by service classes and the time of pre-booking a ticket.

Let us start with the analysis of fuel prices. Table 2 shows the average value of the coefficient of variation of prices for the respective samples and for the whole market.

As we can see, the segmental values of the coefficient of price variation are quite low, varying in the range from 2 to $5 \%$
Table 2

Average value of price variation across the segments of the retail fuel market in Ukraine and all totalled [5]

\begin{tabular}{|l|c|}
\hline \multicolumn{1}{|c|}{ Market segment } & Average value of price variation, $\%$ \\
\hline A-95 motor gasoline & 5.09 \\
\hline A-92 motor gasoline & 4.33 \\
\hline Diesel fuel & 2.07 \\
\hline Liquefied natural gas & 4.95 \\
\hline All totalled & 22.67 \\
\hline
\end{tabular}

and indicating severe price competition between different gas station networks. The differences between the prices set by different retailers at their gas stations are insignificant. In fact, they cannot be significant, because it will force consumers to switch to buying the fuel from the retailer with significantly lower prices. The homogeneity of products within the segment and the requirement of its compliance with uniform standards make the consumer to some extent insensitive to the place of purchase of fuel. Our survey showed that only a quarter of motorists would continue to buy fuel at the basic gas station in the case of small but significant and non-transitory increase in price (SSNIP-test), while others expressed their willingness to look for cheaper gas at competitors' gas stations. This value is too low to let fuel retailers ignore competitors' prices.

The overall differentiation of fuel within the market increases the coefficient of variation to $22.67 \%$, but this figure can hardly be considered as a correct indicator of harshness of price competition, since prices are set separately for each type of fuel, and consumers are usually unable to switch from one type of fuel to another because of the technical characteristics of their cars' combustion engines. Exception is only different types of gasoline (A-95, A-92, etc.), between which a consumer can switch under certain circumstances, while the proportion of such switching does not promise to be high. Only $9.7 \%$ of motorists said they would do it with ease. The statistic mode for the sample of respondents on this question is 8 in the range from 1 to 10 , where 1 means easy switching, and 10 - refusal from switching.

Another kind of acknowledgment of severe price competition within the retail fuel market is the constant interest of the Antimonopoly Committee of Ukraine (AMCU) in their activities from the perspective of their matching to some kind of collusive practices. Last few years was marked by the range of AMCU charges of infringement of competition law by the leading Ukrainian petroleum retailers. They include the AMCU decision No. 480-r dated 28.10.2016 on collusion between LLC "Golden Equator", LLC "WOG Retail", PE "Okko Oil Product", LLC "Alliance Holding", LLC "SOCAR PETROLEUM",LLC "Parallel - M LTD", AMIC Ukraine FDI [8]; AMCU decision No. 315-r dated 21.06.2018 on collusion between the companies of Nadezhda Group, WOG Group, OKKO Group, LLC "Avantage 7" and LLC "Factoring Group" [9]; AMCU decision No 329-r dated 14.05.2019 on collusion between companies of the WOG Group, LLC "SOCAR PETROLEUM", LLC "OKKO-Retail" [10]. The price collusion is a logical response of the oligopolistic market to severe price competition, since the latter washes away the resources needed to develop companies; it makes the retailers' economic profits too small.

In recent years, the non-price competition among petroleum retailers has been intensified. It manifests through implementation of loyalty programs, expanding the list and improving the quality of ancillary retail services, and others. However, the impact of these non-price factors onto the price is still small enough, maintaining the price corridor within the scope of search costs.

The situation in the market of air-passenger operations is reverse. As noted above, we investigated prices for services of 17 different airlines (in general and per $1 \mathrm{~km}$ distance) for 
50 destinations with departure from Kyiv in July-August 2018, ranged by service classes and the time of pre-booking the ticket. This sample was also analysed with the coefficient of price variation (Table 3).

Table 3 shows that the price variation in the market of airpassenger operations is ten times higher than the similar indicators for the retail fuel market, illustrating much weaker price competition between air carriers. In this market, even the residues of price competition are covered by non-price ones. Higher/lower fares are set here under the pretext of varying quality of service. For example, the distribution of airlines into premium carriers (Qatar Airways, Emirates, Lufthansa, Turkish airlines, KLM), middle class (UIA, LOT, Belavia, AirMoldova, Czech airlines) and low cost carriers (RyanAir, Smart Wings, Pegasus, Wizzair) is associated by most consumers to a greater extent with the different quality of the service than with the price per se. The average consumer is aware that low-cost companies usually limit the range of additional services (luggage, food, and others) by requiring additional fee; as a rule, it is impossible to return their tickets in case of non-flight; some of them do not even provide for determining the position of the passenger on board, allowing passengers to occupy the seats themselves. Flying with a premium airline will always be much more comfortable, including the number of free services, which costs are included into the higher price of a ticket. That means that we are dealing with the classic case of vertical differentiation. Such differentiation, by increasing the reserve price of goods, makes competition between market actors less severe, while consumers do not find such a practice illegitimate.

In fact, the result of such legitimation of competitive strategies of airlines in Ukrainian market is the absence of complaints to the AMCU about the violation of the competition law by airlines. Ukrainian antitrust practices knew the cases of vertical concerted action between airports and airlines, caused by naturally monopolistic status of the airports, while horizontal competition in the market did not cause any criticism from the AMCU. The reason is considerable differentiation and information asymmetry. The latter ones act both as a deterrent to conspiracy, reducing the coordination capacity of the market, and as an argument for the consumer to pay more.

A modern carrier is very convincing in its justification for the high cost of the service provided, especially since the cost itself is very difficult to calculate. Inflated levels of published fares are actively used by airlines to illustrate consumer discounts.

The above-mentioned does not mean that there is no price competition in the market of air-passenger operations. It exists not only within the different classes of quality of transport services, but also blurring the boundaries between classes with discounts as mentioned above. However, in this market price competition is not decisive, being a result of non-price competition of speed of flight, convenience of a schedule, quality of service and so on.

\section{Table 3}

Average value of price variation across the segments of the market of air-passenger operations in Ukraine and all totalled*

\begin{tabular}{|l|c|c|}
\hline \multirow{2}{*}{$\begin{array}{c}\text { Differentiation criterion } \\
\text { (cumulative) }\end{array}$} & \multicolumn{2}{|c|}{ Average value of price variation, $\%$} \\
\cline { 2 - 3 } & $\begin{array}{c}\text { at the absolute } \\
\text { value of airfare }\end{array}$ & $\begin{array}{c}\text { at airfare per } \\
1 \mathrm{~km} \text { of a flight }\end{array}$ \\
\hline All totalled & 127.73 & 79.84 \\
\hline Flight itinerary & 62.91 & 64.98 \\
\hline Flight itinerary and service class & 38.8 & 39.85 \\
\hline $\begin{array}{l}\text { Flight itinerary, class of service } \\
\text { and ticket booking period }\end{array}$ & 33.54 & 34.01 \\
\hline
\end{tabular}

* according to the data of travel fare aggregators, such as skyscanner, tickets.ua, kyiavia, tripadvisor, avianews.com
Conclusions. Summarizing the results of the comparative analysis of competition in the retail fuel market and the market of air-passenger operations, we can make the next conclusions. In the retail fuel market, which is characterized by a minimum level of information asymmetry, sellers are forced to resort to severe price competition or to make cartels. In the market of air-passenger operations competition is much weaker, while the set of parameters by which it occurs is much wider. The information asymmetry of the latter deforms a consumer perception of the market equilibrium parameters so much that lower intensity of competition and wider range of equilibria are not perceived by him/her as a bad, while a seller obtains some kind of guarantee of positive economic profit as a source for innovative development. In the retail fuel market, the expansion of the range of equilibria is always perceived by consumers as some kind of abusive practice, keeping sellers in a narrow price corridor, weakening their adaptive efficiency.

Markets in the economy are interconnected by capital flows, so the inter-sectoral imbalance described above is not stable. It will provide a leak of capital from one industry to others (however, there are effective safeguards like demand constraints or other market barriers) or it will multiply the practice of applying more effective competitive strategies. Nowadays we can already observe a gradual increase in differentiation and information asymmetry in the retail fuel market. According to AMCU, such leading market actors as LLC "WOG Retail" and LLC "OKKO-Retail" sell no more than $20 \%$ of fuel at prices, which are set on their information boards (nominal prices), while the rest is sold through discounts within loyalty programs. Even the price correlation between nominal prices has been reducing over years (in 2016 average value of price correlation coefficient was 0.97 ; in $2017-0.95$, in $2018-0.92$ ). Therefore, in the nearest future, we should expect significant changes in the nature of competition within the recently transparent markets, its sophistication and differentiation in the non-price area that requires revision of the competition strategies themselves and approaches to control over latter by competitive agencies to counteract the new generation of anticompetitive practices.

\section{References.}

1. Decourt, R. F., Almeida, H., \& Protin, P. (2017). Informational Asymmetry Index. In VIII Congresso Brasileiro de Administração e Contabilidade October 19-21, 2017, (pp. 1-13). Rio de Janeiro. Retrieved from: http://adcont.net/index.php/ adcont/AdCont2017/paper/viewFile/2666/761.

2. Martins, O. S., \& Paulo, E. (2014). Information asymmetry in stock trading, economic and financial characteristics and corporate governance in the Brazilian stock market. Revista Contabilidade \& Finanças, 25(64), 33-45.

3. Jonson, T. L., \& So, E.C. (2017). A Simple Multimarket Measure of Information Asymmetry. Management Science, 64(3), 983-1476.

4. Boru, T., \& Kuhil, A. M. (2018). The Structure Conduct Performance Model and Competing Hypothesis- a Review of Literature. Research Journal of Finance and Accounting, 9(1), 76-89. 5. SC "Psyche" (2018). Dynamics of fuel prices and retail turnover. Retrieved from: https://psychea.com.ua/psyfuel/display/2368/. 6. MIU, Ministry of Infrastructure of Ukraine (2018). News. Official web site of the Ministry of Infrastructure of Ukraine. Retrieved from: https://mtu.gov.ua/timeline/Novini.html/.

7. CMU, Cabinet of Ministers of Ukraine (1997). Rules of petroleum retail trade: Approved by the Decree of the Cabinet of Ministers of Ukraine No. 1442 dated 20 Dec.1997. Retrieved from: https://zakon.rada.gov.ua/laws/show/1442-97-\%D0\%BF.

8. AMCU, Antimonopoly Committee of Ukraine (2016). Decision on the Case No. 128-26.13/112-16. Retrieved from: http://www.amc.gov.ua/amku/doccatalog/ document?id $=131325 \&$ schema $=$ main.

9. AMCU, Antimonopoly Committee of Ukraine (2018). Decision on the Case No. 128-26.13/102-17. Retrieved from: 
http://www.amc.gov.ua/amku/doccatalog/ document?id=142751\&schema $=$ main.

10. AMCU, Antimonopoly Committee of Ukraine (2019). Decision on the Case No. 128-26.13/142-17. Retrieved from: http://www.amc.gov.ua/amku/doccatalog/ document?id=149657\&schema=main.

\section{Інформаційна асиметрія як детермінанта конкурентної боротьби}

\section{Н. А. Мазаракі, А. Г. Герасименко, В. Ю. Ковтун}

Київський національний торговельно-економічний університет, м. Київ, Україна, e-mail: n.mazaraki@knute.edu. ua; a.gerasymenko@knute.edu.ua

Мета. Визначення впливу інформаційної асиметрії на базові стратегії конкурентної боротьби між учасниками ринку, з'ясування очікуваного вектору зміни конкуренції в міру посилення інформаційної асиметрії.

Методика. Теоретико-методологічним підгрунтям дослідження є компаративний аналіз ринків роздрібної торгівлі пальним в Україні та пасажирських авіаперевезень. Зазначені ринки розглядаються як приклади ринків, які за однакових структурних параметрів характеризуються різним рівнем інформаційної асиметрії, що дозволяє встановити вплив інформаційної асиметрії на конкуренцію.

Результати. Порівняння ринку роздрібної торгівлі пальним і ринку пасажирських авіаперевезень свідчать про те, що інформаційна асиметрія впливає на вибір учасниками ринку основної стратегії конкуренції. Так, інформаційна асиметрія послаблює цінову конкуренцію та збільшує нецінову, загалом послаблюючи інтенсивність конкуренції між учасниками ринкових відносин i формуючи передумови для підвищення їх динамічної конкурентоспроможності. Цей вплив інформаційної асиметрії на конкуренцію й суспільний добробут є, переважно, позитивним. У той же час спостерігається тривалий негативний ефект - інформаційна асиметрія деформує споживче сприйняття параметрів ринкової рівноваги настільки, що менша інтенсивність конкуренції й ширший діапазон рівноваги не сприймаються негативно, а продавець отримує гарантію додатного економічного прибутку. Цей негативний ефект укорінюється через поширення інформаційної асиметрії (як вигідної та законної практики) по ринках, забезпечуючи іï посилення. Останнє вимагає розробки нових підходів до оцінки ефективності ринкової конкуренції, тоді як парадигма «структура - поведінка - результат» дає позитивні результати.

Наукова новизна. У ході проведення дослідження нами був зроблений висновок, що класифікація благ, відповідно до міри їх сприятливості до інформаційної асиметрії на розшукувані, товари, що перевіряються, та товари на довірі, є суто теоретичною. У чистому вигляді на практиці вони практично не зустрічаються, саме тому нами була розроблена спеціальна крива схильності до інформаційної асиметрії, на якій товари, що наближаються до статусу товарів на довірі, мають найбільшу схильність до проявів інформаційної асиметрії.

Практична значимість. Запропонована у роботі методика дослідження ринків може виступати підгрунтям для більш ефективного вибору конкурентної стратегії з боку суб'єктів господарювання або ж більш ефективного дослідження ситуації на ринках консалтинговими агентствами та органами державної влади.

Ключові слова: інформаційна економіка, інформаційна асиметрія, конкуренція, цінова конкуренція, диференціація товарів, роздрібний ринок пального, ринок пасажирських авіаперевезень

\section{Информационная асимметрия как детерминанта конкурентной борьбы}

\section{Н. А. Мазараки, А. Г. Герасименко, В. Ю. Ковтун}

Киевский национальный торгово-экономический университет, г. Киев, Украина, e-mail: n.mazaraki@knute.edu. ua; a.gerasymenko@knute.edu.ua

Цель. Определение влияния информационной асимметрии на базовые стратегии конкурентной борьбы между участниками рынка, выяснение ожидаемого вектора изменения конкуренции по мере усиления информационной асимметрии.

Методика. Теоретико-методологическим основанием исследования является компаративный анализ рынков розничной торговли горючим в Украине и пассажирских авиаперевозок. Указанные рынки рассматриваются как примеры рынков, которые при одинаковых структурных параметрах характеризуются разным уровнем информационной асимметрии, что позволяет установить влияние информационной асимметрии на конкуренцию.

Результаты. Сравнение рынка розничной торговли горючим и рынка пассажирских авиаперевозок свидетельствуют о том, что информационная асимметрия влияет на выбор участниками рынка основной стратегии конкуренции. Так, информационная асимметрия ослабляет ценовую конкуренцию и увеличивает неценовую, ослабляя интенсивность конкуренции между участниками рыночных отношений и формируя предпосылки для повышения их динамической конкурентоспособности. Это влияние информационной асимметрии на конкуренцию и общественное благосостояние является, преимущественно, положительным. В то же время наблюдается длительный отрицательный эффект - информационная асимметрия деформирует потребительское восприятие параметров рыночного равновесия настолько, что меньшая интенсивность конкуренции и более широкий диапазон равновесия не воспринимаются негативно, а продавец получает гарантию положительной экономической прибыли как источника инновационного развития. Этот негативный эффект приживается из-за распространения информационной асимметрии (как выгодной и законной практики) по рынкам, обеспечивая ее усиление. Последнее требует разработки новых подходов к оценке эффективности рыночной конкуренции, тогда как парадигма «структура поведение - результат» дает положительные результаты.

Научная новизна. В ходе проведения исследования нами был сделан вывод, что классификация благ, в соответствии с мерой их восприимчивости к информационной асимметрии на разыскиваемые, проверяемые товары и товары на доверии, является чисто теоретической. В чистом виде на практике они практически не встречаются, именно поэтому нами была разработана кривая склонности к информационной асимметрии, на которой товары, приближающиеся к статусу товаров на доверии, имеют наибольшую склонность к проявлениям информационной асимметрии.

Практическая значимость. Предложенная в работе методика исследования рынков может выступать основой для более эффективного выбора конкурентной стратегии со стороны субъектов хозяйствования или более эффективного исследования ситуации на рынках консалтинговыми агентствами и органами государственной власти.

Ключевые слова: информационная экономика, информационная асимметрия, конкуренция, ценовая конкуренция, дифференциация товаров, розничный рынок топлива, рынок пассажирских авиаперевозок

Recommended for publication by H.V.Duhinets, Doctor of Economic Sciences. The manuscript was submitted 20.05.19. 